\title{
The Analysis of Legal, Accounting, and Tax Issues in Selecting Partnership Scheme for The Geothermal Power Plant Project (Case Study of PT ABC)
}

\author{
Jenny Kanprilla*, Ning Rahayu** \\ * Faculty of Economics and Business, Universitas Indonesia \\ ** Faculty of Administrative Science, Universitas Indonesia \\ DOI: 10.29322/IJSRP.12.01.2022.p12152 \\ http://dx.doi.org/10.29322/IJSRP.12.01.2022.p12152
}

\begin{abstract}
This paper aims to identify the legal, accounting, and tax issues faced by PT ABC in selecting one of the three partnership schemes for conducting the geothermal power plant project in Area X. The first scheme is PT ABC sign a Joint Operation Contract with AP-PLN to conduct the total project where PT ABC are responsible to develop the upstream side while AP-PLN are responsible to develop the downstream side. The second scheme is PT ABC and AP-PLN form a Joint Venture company at first then PT ABC will sign a Joint Operation Contract with the Joint Venture company of PT ABC and AP-PLN. The last scheme is PT ABC and AP-PLN form a Joint Venture company to conduct the total (integrated) project in Area X. The research approach used is descriptive qualitative with the case study as a research strategy. Primary data was obtained from semi-structured in-depth interviews with PT ABC, the Indonesian Ministry of Energy and Mineral Resources, and taxation academics. The secondary data was obtained from PT ABC and AP-PLN joint study report, the laws and regulations governing geothermal and its tax treatment in Indonesia. The results show that the legal issue faced by $\mathrm{PT} \mathrm{ABC}$ in the first and the second scheme is law uncertainty because the regulation governing partnership schemes for Geothermal Concession holder is unavailable other than PT Pertambangan Minyak dan Gas Bumi Negara's Joint Operation Contract in accordance with the Indonesian Presidential Decree Number 22 Year 1981. The legal issue faced by PT ABC in the third scheme is there is no regulation that explicitly permits the transfer of Geothermal Concession over Area X from Geothermal Concession holder to other entity. There are differences between accounting and tax treatment of the Joint Operation scheme as applied in the first and the second scheme. In accounting, the recording of Joint Operation's assets, liabilities, incomes, and expenses are carried out by each party. Meanwhile, in tax, Joint Operation considered as if separate entities so that the recording of assets, liabilities, incomes and expenses are carried out by the Joint Operation alone aligned with the Article 4 Paragraph (3) Indonesian Director General of Taxes (DGT) Regulation Number PER-04/PJ/2020. Other tax issue faced by PT ABC is the tax regime differences between the first and second scheme which are obliged to pay the Government Portion Deposit in the amount of $34 \%$ (thirty four percent) from Net Operating Income by quarterly according to the Indonesian Minister of Finance Regulation Number 90/PMK.02/2017 and apply the Value Added Tax (VAT) reimbursement on the acquisition of taxable goods and/or taxable services as the old geothermal tax regime. Meanwhile, the third scheme applies the Income Tax and VAT Law general provisions as the new geothermal tax regime. Thus, the Joint Venture company of PT ABC and AP-PLN does not have to pay the Government Portion Deposit and does not apply VAT reimbursement.
\end{abstract}

Index Terms- Legal, Accounting, Tax, Geothermal, Partnership Scheme

\section{INTRODUCTION}

Tndonesia is the second country with the largest geothermal potency in the world, reaching 23.965,5 MW (ESDM, 2020). This potency becomes one of the strengths for Indonesia to be able to carry out its commitment to reduce the greenhouse gas emission levels and green energy programs in accordance with the Kyoto Protocol and the Paris Agreement which both aim to tackle climate change globally. However, the level of geothermal utilization in Indonesia is still low, reaching only 2.175,7 MW until 2020 or $9 \%$ (nine percent) of the total geothermal potency owned by Indonesia (ESDM, 2020). The high costs and high upfront risks become the factors of the low level of geothermal utilization in Indonesia. As an alternative, most of geothermal companies conduct the development activities by forming a partnership scheme. PT ABC is one of the geothermal companies in Indonesia who will apply a partnership scheme with AP-PLN to conduct the geothermal power plant project in Area X.

Based on the joint study report between PT ABC and PT AP-PLN, there are 3 (three) alternative partnership schemes proposed for the geothermal power plant project in Area X, they are: (1) Joint Operation between PT ABC and AP-PLN, (2) Joint Operation between PT ABC and the Joint Venture of PT ABC and PT AP-PLN, and (3) Joint Venture between PT ABC and AP-PLN. In this case, PT ABC is the Geothermal Concession holder of Area X and it refers to the era before the enactment of Law Number 27 Year 2003 
concerning geothermal. The era is called as existing era. In that era, there was no regulation in the form of a Law that specifically regulated geothermal exploration and exploitation activities in Indonesia, including the provisions governing the rights of geothermal company to form partnership schemes in carrying out geothermal development. The only one partnership scheme regulated in the existing era was the Joint Operation Contract which conducted by PT Pertambangan Minyak dan Gas Bumi Negara (PT Pertamina) according to the Fourth Dictum of Indonesian Presidential Decree Number 22 Year 1981. The other issues faced by PT ABC in selecting partnership scheme for the geothermal power plant project in Area $\mathrm{X}$ is accounting and tax issues. In accounting, the financial accounting standards regarding partnership schemes are regulated in Statement of Financial Accounting Standards Number 66 - Joint Arrangements (PSAK 66 - Pengaturan Bersama) where states that partnership schemes can be divided into 2 (two) forms, they are Joint Operation and Joint Venture. In tax, there are two geothermal tax regimes that apply in Indonesia, they are the old geothermal tax regime and the new geothermal tax regime. The old geothermal tax regime applies the obligation to pay Government Portion Deposit in the amount of 34\% (thirty four percent) from Net Operating Income by quarterly according to the Indonesian Minister of Finance Regulation Number 90/PMK.02/2017 and applies VAT reimbursement. Meanwhile, the new geothermal tax regime applies the Income Tax and VAT Law general provisions.

\section{CONCEPTUAL FRAMEWORKS}

\section{A. The Concept of Joint Venture}

Joint Venture is defined as an entity formed separately, consisting of two or more companies active as partners, and formed to increase productivity and profits from cooperation between partner companies (Harrigan, 1986). According to Grant (2012), Joint Ventures are a common scheme applied by companies in the oil and gas mining sector, as well as the New and Renewable Energy (NRE) sector because the costs required to carry out projects in these sectors are relatively high.

\section{B. The Concept of Joint Operation}

The term Joint Operation (JO) is also often referred as a Joint Operating Agreement (JOA). Peters et. al. (2012) defined Joint Operation as a binding agreement or agreement between two or more parties jointly to contribute to financing, intelligence, access to markets, access to exploration projects, and natural resource development with a clear and limited scope for each party. Unlike a Joint Venture, a JO or JOA does not lead to the formation of a new company so that the business can be run without a jointly formed company but can be run only based on the contract/agreement itself. Another difference between a JO or JOA and a Joint Venture is that the partners can recognize the rights to the assets and costs on a proportionate basis instead of recording them as an equity.

\section{RESULTS}

There are 3 (three) aspects regarding to the existence of a business entity. They are legal, accounting, and tax aspect. Analyzing the issues of legal, accounting, and tax aspect faced by PT ABC in selecting one of the three partnership schemes is required to determine the most likely partnership scheme to conduct the geothermal power plant project in Area X. There are 3 (three) alternative partnership schemes proposed for the geothermal power plant project in Area X, they are: (1) PT ABC sign a Joint Operation Contract with AP-PLN to conduct the total project where PT ABC are responsible to develop the upstream side while AP-PLN are responsible to develop the downstream side, (2) PT ABC and AP-PLN form a Joint Venture company at first then PT ABC will sign a Joint Operation Contract with the Joint Venture company of PT ABC and AP-PLN, and (3) PT ABC and AP-PLN form a Joint Venture company to conduct the total (integrated) project in Area X. The illustration of each partnership scheme is shown in Figure 1 and the analysis of legal, accounting, and tax issues faced by PT ABC in each partnership scheme are explained as follows:

\section{A. Legal Issues}

The first scheme is PT ABC sign a Joint Operation Contract with AP-PLN to conduct the total project where PT ABC are responsible to develop the upstream side while AP-PLN are responsible to develop the downstream side. If the first scheme is applied, there will be no new company formation but the two companies, namely PT ABC and AP-PLN are jointly responsible to conduct the total project in Area X. Because the Joint Operation does not form a new company, there is no transfer process of the Geothermal Concession over Area X, but the Geothermal Concession is still owned by PT ABC. Hence, this scheme will not cause the transfer of Geothermal Concession as the Law Number 21 Year 2014 (2014 Geothermal Law) prohibits the transfer of Geothermal Permit. The legal issue will be faced by PT ABC because there is no regulation that explicitly stipulates that the Minister can appoint other parties to act as operation management to enter into cooperation other than PT Pertamina. In this case, PT ABC does not have a strong legal standing to apply a Joint Operation scheme with AP-PLN for conducting the geothermal power plant project in Area X. 
The second scheme is PT ABC and AP-PLN form a Joint Venture company at first then PT ABC will sign a Joint Operation Contract with the Joint Venture company of PT ABC and AP-PLN. Like the first alternative partnership scheme, the second partnership scheme does not involve the transfer process of Geothermal Concession over Area X, but the Geothermal Concession remains owned by PT ABC. Therefore, this alternative partnership scheme does not contrary with the 2014 Geothermal Law which prohibits the transfer of Geothermal Permit. However, the Joint Operation scheme which permitted by Indonesian Government is Joint Operation in accordance with the Indonesian Presidential Decree Number 22 Year 1981, that is only PT Pertamina which at that time was appointed as the Geothermal Concession holder in Indonesia. Meanwhile, there is no regulation governing Joint Operation other than PT Pertamina as the operation management. Thus, there is no strong legal standing for PT ABC applying a Joint Operation scheme with the Joint Venture of PT ABC and AP-PLN.

The third scheme is forming a Joint Venture of PT ABC and AP-PLN which causes a separate business entity formation. The consequence that will arise due to the formation of a Joint Venture between PT ABC and AP-PLN is that the Joint Venture company must have its own permit to conduct the development project over Area X. It will lead a transfer process of Geothermal Concession from PT ABC as the Concession holder to the Joint Venture company. In this case, the kind of permit over Area X is a Geothermal Concession which was obtained by PT ABC prior to the enactment of the 2014 Geothermal Law. In the era, there was no regulation that stipulated the prohibition of Geothermal Concession transfer as the 2014 Geothermal Law prohibits the Geothermal Permit transfer. Thus, the transfer of Geothermal Concession from PT ABC to the Joint Venture company of PT ABC and AP-PLN can cause legal problems in future.

\section{B. Accounting Issues}

The Statement of Financial Accounting Standards Number 12 - Joint Control (PSAK 12 - Pengendalian Bersama) is no longer valid and has been replaced by Statement of Financial Accounting Standards Number 66 - Joint Arrangements (PSAK $66-$ Pengaturan Bersama). Statement of Financial Accounting Standards Number 66 - Joint Arrangements defined a joint arrangement as an arrangement in which two or more parties have a joint control. Basically, there are 2 (two) types of joint arrangements according to Statement of Financial Accounting Standards Number 66 - Joint Arrangements, they are as follows:

1. Joint Operation; and

2. Joint Venture

There are differences between accounting and tax treatment of the Joint Operation scheme as applied in the first and the second scheme. In accounting, the recording of joint operation's assets, liabilities, incomes, and expenses are carried out by each party. Meanwhile, in tax, Joint Operation considered as if a separate entity so that the recording of assets, liabilities, incomes and expenses are carried out by the Joint Operation alone.

\section{Tax Issues}

After the issuance of the Indonesian DGT Regulation Number PER-04/PJ/2020, the status and tax treatment of Joint Operation, both the Income Tax and VAT treatment, has been clarified so that there should no longer be any different interpretation related to the status and tax treatment of Joint Operation. However, there are issues regarding the treatment differences between accounting and tax on Joint Operation. Even though in terms of accounting and tax, Joint Operation has same definition, but the treatment is different. From an accounting perspective, a Joint Operation does not lead a new company formation so that it is not treated as a separate entity while in tax term, a Joint Operation is considered as a separate entity which is obliged to pay and report their own Corporate Income Tax on behalf of the Joint Operation as stipulated in the provisions of Article 6 Paragraph (3) letter a PER-04/PJ/2020. With the obligation to pay and report their own Corporate Income Tax on behalf of the Joint Operation, indirectly the Joint Operation is obliged to maintain its own bookkeeping. Meanwhile, the tax treatment for Joint Venture is the same as the tax treatment for Corporate Tax Subjects as referred to the provisions of Article 2 Paragraph (1) letter b of the Income Tax Law. Furthermore, the other tax issue faced by PT ABC is the tax regime differences between the first and second scheme which are obliged to pay the Government Portion Deposit in the amount of 34\% (thirty four percent) from Net Operating Income by quarterly according to the Indonesian Minister of Finance Regulation Number 90/PMK.02/2017 and apply the VAT reimbursement on the acquisition of taxable goods and/or taxable services as the old geothermal tax regime while the third scheme refers to the Income Tax Law which is subject to a Corporate Income Tax rate of 22\%. In addition, the new geothermal tax regime also does not apply VAT reimbursement mechanism so that the VAT on acquisition of taxable goods and/or taxable services can be treated as a deduction from gross income in accordance with the provisions of Article 6 Paragraph (1) number 9 of the Income Tax Law. 


\section{CONCLUSION}

There are legal, accounting, and tax issues faced by PT ABC in each of the partnership schemes for the geothermal power plant project in Area X. The legal issue faced by PT ABC in the first and the second scheme is law uncertainty because the regulation governing partnership schemes for Geothermal Concession holder in existing era is unavailable other than PT Pertamina's Joint Operation Contract according to Indonesian Presidential Decree Number 22 Year 1981. Hence, the first and the second scheme may not be possible to be applied in this project. The legal issue in the third scheme is also law uncertainty because there is no regulation that explicitly permits or prohibits the transfer of Geothermal Concession from Geothermal Concession holder to other entity which in this case, PT ABC have to transfer its Geothermal Concession to Joint Venture company of PT ABC and AP-PLN. Other issues are the accounting and tax issues. There are differences between accounting and tax treatment of the Joint Operation as applied in the first and the second scheme. In accounting, the recording of Joint Operation's assets, liabilities, incomes, and expenses are carried out by each party. Meanwhile, in tax, Joint Operation considered as a separate entitiy so that the recording of assets, liabilities, incomes and expenses are carried out by the Joint Operation alone aligned with the Article 4 Paragraph (3) Indonesian DGT Regulation Number PER-04/PJ/2020. Other tax issue faced by PT ABC is the tax regime differences between the first and second scheme which are obliged to pay the Government Portion Deposit in the amount of 34\% (thirty four percent) from Net Operating Income by quarterly according to the Indonesian Minister of Finance Regulation Number 90/PMK.02/2017 and apply the VAT reimbursement on acquisition of taxable goods and/or taxable services as the old geothermal tax regime. Meanwhile, the third scheme applies the Income Tax and VAT Law general provisions as the new geothermal tax regime. Thus, the Joint Venture of PT ABC and AP-PLN does not apply the obligation to pay Government Portion Deposit and does not apply VAT reimbursement mechanism.

\section{APPENDIX}

Figure 1. Illustration of The Three Alternative Partnership Schemes between PT ABC and AP-PLN for The Geothermal Power Plant Project in Area X

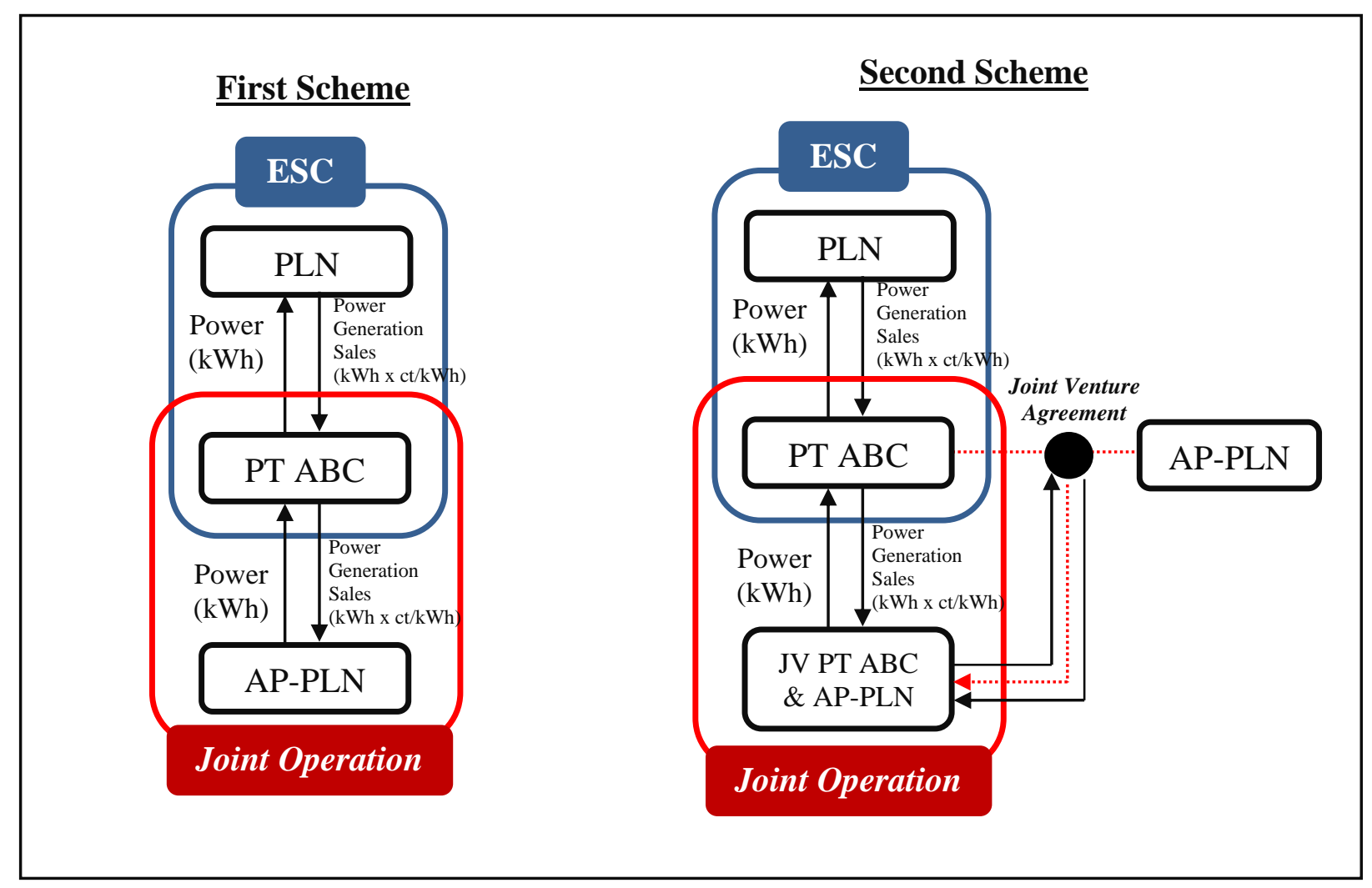


Figure 1. Illustration of The Three Alternative Partnership Schemes between PT ABC and AP-PLN for The Geothermal Power Plant Project in Area X (continued)

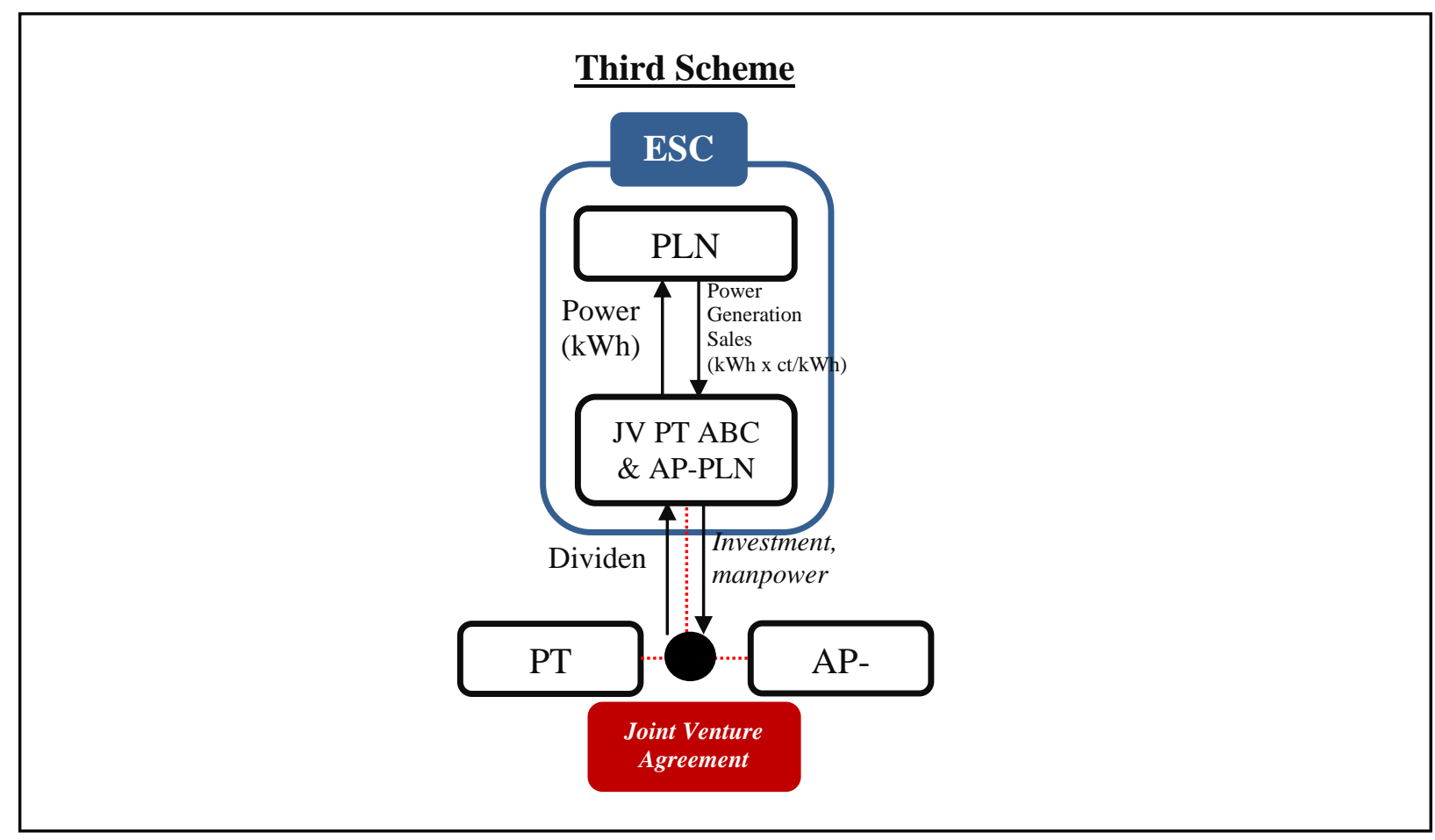

\section{REFERENCES}

[1] Ebtke.esdm.go.id, 30 Juli 2020, https://ebtke.esdm.go.id/post/2020/07/30/2598/potensi.besar.panas.bumi.diharap.mampu.dongkrak.bauran.energi. Diakses pada 10 Februari 2021

[2] Grant, Brad. (2012). Joint Ventures in the Canadian Energy Industry. Vol 50, No 2: Energy Law Edition. doi: https://doi.org/10.29173/alr254

[3] Harrigan, K. R. (1986). Managing for Joint Venture Success. Lexington, Mass: Lexington Books.

[4] Peters, M., \& Kumar, M. (2012). Why international oil companies choose to enter into joint operating agreement. Acta Juridica Hungarica, 53(2), 175-180. https://doi.org/10.1556/AJur.53.2012.2.5

\section{AUTHORS}

First Author - Jenny Kanprilla, Post-graduate Student, Universitas Indonesia, jennykanprilla@ gmail.com.

Second Author - Ning Rahayu, Lecturer, Universitas Indonesia, ning.rahayu@ yahoo.com.

Correspondence Author - Jenny Kanprilla, jennykanprilla@gmail.com, jennykanprilla81@ui.ac.id. 